\title{
Economic Benefits of Market Liberalization. Evidence from Air Transport in Poland
}

\author{
Mgr Sonia Huderek-Glapska \\ Department of Microeconomics \\ Poznań University of Economics \\ sonia.buderek@ue.poznan.pl
}

\begin{abstract}
This paper focuses on economic effects that are a consequence of air transport liberalization in Poland after accession to European Union. Scenario analysis was built to estimate the impact of changes on the international aviation market, including passenger traffic, airport revenues and employment. The analysis is estimated on and applied to Polish market in the time period before and after market deregulation in 2004. Enabling airlines to open new routes and to offer services at lower prices results in vigorous development of number of flights. The passenger traffic at Polish airports in 2009 was of 18,9 million which means more than a double increase when compared to 2003 (7,1 million). Increased number of flights affects local economy. Removing restriction on access to air transport market has created additional PLN 0,96 billion (or EUR 0,24 billion) of main airports sales revenue in Poland over 2004-2008 time period. The passenger traffic has created more than 19 thousand jobs located on-site and off-site at main Poland's airports in 2008. One can assume that if not for the market policy change and the air traffic vigorous development, the total direct employment number in 2008 would be twice as small.
\end{abstract}

Keywords: liberalization, air transport, polish airports, economic impact.

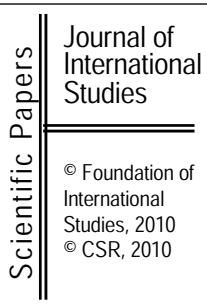

Submitted: May, 2010 $1^{\text {st }}$ revision: May, 2010 Accepted: July, 2010

JEL classification: L43, L93

\section{Introduction}

This paper is purposed to identify and measure the economic impact of Poland's air transport liberalization arrangement with European Union in 2004. The changes in policy that govern access to the market have made the competition fierce and international. The number of air carrier has risen and overall number of flights has experienced a dynamic growth. New routes have been opened, competition on already existing connections has increased, fares have gone down, air mobility of society has risen, revenues of airlines, airports and other aviation business related companies have grown up and employment experienced a rapid boost. In particular, regional airports have experienced enormous growth due to new airlines entrance allowed by market deregulation.

Among many other things, the removal of market restrictions affected directly welfare in economy, output and employment. This paper focuses on economic impact which the market deregulation had and still has on passenger traffic, airports revenues and employment at the on- and offside airport area. Of course, these areas are not the only ones influenced by 
the liberalization of air service in Poland. Furthermore, there are social and environmental aspects. However the knowledge of economic consequence is essential in making a rational decision regarding changes in market regulations.

In order to measure the effect of changes in market regulations, scenario analysis was conducted. The comparison of the welfare level achieved under actual regulation policy with the level that would have been achieved if an alternative regime had been in effect at the same time was made. A linear regression model was constructed in order to predict the air traffic volume that could occur if there has not been for a change in government control of the market. Trend line was constructed based on number of flights in time series before 2004 . Both the airports revenue and the employment in "counterfactual scenario" were estimated on air passenger traffic. Data was collected directly from airports and Civil Aviation Authorities in Poland. Estimated figures are presented both in current and constant prices with reference to 2004 .

Both terms - liberalization and deregulation - are used interchangeably and refer to changes in air transport policy, including freedom to provide air services, regulation of access to the market, establishing new routes, setting prices and giving air carriages licenses. In this paper air traffic refers to carriage of passengers in regular, scheduled flights.

The organization of paper is as follows. Next part illustrates supply side of air transport in Poland under government regime. In section three liberalization process in the US, Western Europe and Poland is presented. Part four provides data concerning air traffic development in Poland after market deregulation. Effects of changes in air transport policy including growth of market volume, development of route structure, customer benefits and growth of aviation business - are listed in part five. Measures of output and employment are provided in section six. The last part contains conclusions.

\section{Air Transport Market in Poland before liberalization}

At the very beginning air transport in Poland - just like in case of other European markets - was nationalized. Airlines and airports were considered to be public entities with a purpose of serving national interests. The management of airports and air carriers was passed on to the state authorities. The market was dominated by national carrier PLL LOT and the airports were controlled by national enterprise PP Porty Lotnicze. International flights were regulated with bilateral agreements with foreign countries. The number of connections was limited and national carrier received preferential treatment.

The network of airports in Poland consists of one central airport located in capital city - Warsaw - and eleven regional airports situated all over the country. The number of served passengers and the ownership character differentiate these airports. Until mid-1990's air traffic in Poland was centralized which means more than $80 \%$ of scheduled flights were offered at the central airport Warsaw and the main role of flights from regional airports was to deliver passengers to hub airports. Regular air traffic in Poland was the example of the huband-spoke system.

Air transport services were regarded as a luxury good, rarely available for an ordinary citizen. Passenger profile was dominated by business traffic. A potential for air services was there however, and still is. Poland - with 38 million citizen - stands out from the New Accession Countries group. The air mobility index of Poles is very low compared with the average of European Union ${ }^{1}$. Growing economy as well as increase in income make the citizens more willing to travel. Furthermore, Poland has become attractive to international

\footnotetext{
${ }^{1}$ Air mobility index in Poland was of 0,5 in 2009 (0,15 in 2002) which means that statistically each citizen makes on average one air travel per two years whereas the EU average reaches 2 flights per year. Currently the highest rate of air travel per citizen is present in Norway, amounting almost 6 flights per year.
} 
tourists. One can assume that removing regulatory burden from air transport would allow to develop its potential even further.

\section{Liberalization process}

After Second World War civil aviation has been strictly regulated for economic and social reason. The first step toward liberalization in air transport market has been taken by United States of America. In late 1978 the U.S. government implemented Airline Deregulation Act which removed many regulated areas of commercial aviation. (The Airline Deregulation Act, 1978). Before 1978, airlines - in order to enter the market - had to demonstrate that a given service was required by public convenience and necessity (Morrison, Winston, 1986).

In Europe the wave of change has come in during the last two decades of the twentieth century. The EU has taken step forward in deregulating air transport sector with the provision in the three "packages" of liberalization measures in 1987, 1990 and 1993 (Button and Stough, 2000). These packages had gradually introduced freedom to provide air services within Europe and were regulating rules of access to the market, establishing new routes, setting prices and giving air carriage licenses. The freedom to provide right for an airline of one Member State to operate on a route within another Member State (so called cabotage) was adopted in April 1997 (Button and Stough, 2000). However the impulse for change has been given much earlier. The way for air transport liberalization in Europe has been paved by the United Kingdom. During the 80's the policy of UK government civil aviation has been influenced by US deregulation. The UK was an initiator of bilateral liberalizing agreements with Members of European Union (Armstrong and Bulmer, 1998).

European countries outside European Union regulated air transport market with bilateral agreements. In Poland this policy has been changing since 1999 when negotiations with European Commission concerning agreement on liberalization of transport market started (CEI, 2002). Poland set transition period for implementing Council Regulation no 2407/92 on licensing air carrier and Regulation no 2408/92 on access for Community air carriers to intra-Community air routes in order to protect operation of national carrier from international competition. At the beginning of 2003 the agreement on common European airspace law was implemented.

The new rules in aviation market that have been in force since applying Council Regulation have made competition fierce and international. Decisions concerning opening new routes, level of fares and offering capacity were based more on economic and financial calculation than on securing national interest. The number of air carriers went up and traffic has experienced a dynamic growth. New routes have been opened, competition in case of already existing connections has increased even further, fares have gone down. Air mobility of society, employment, revenues of airlines, airports and other business related with aviation have also increased.

Deregulated environment has forced aviation companies - airlines in particular - to change their business model. In order to operate in open market air carriers needed to obtain competitive advantage. What's even more important, a new type of airlines has emerged prior to the liberalization - so called Low Cost Carriers, focused on delivering services at minimal possible cost and lowest price.

\section{Air Transport in Poland after market deregulation}

The monopolistic position of the flag carrier at airports, high fares and lack of new direct connections with European cities - all that has changed after adapting air market 
regulations to EU standards during Poland accession to the European Union. After 2004 the Poland's deregulated market slowly started to develop and regional airports revealed their stifled potential. Between 2005-2009 the growth rate of air traffic in Poland was one of the highest in the world. IATA lists Poland at the top of the group with the greatest dynamic of passenger traffic. Scheduled flights were estimated to rise by $11,2 \%$ annual compared to an overall industry average annual growth rate of 5,6\% for international passenger traffic and to $5,1 \%$ within Europe over 2005-2009 time period (IATA, 2005). It has to be noted however that passenger traffic in Poland has developed most dynamically. In 2005 the flights growth rate was of $24 \%$ compared to previous years and remained so high until economic crisis in 2008. The passenger traffic was of 18,9 million in 2009 and has more than doubled itself when compared to 2003, when the number of carried passenger was at a level of 7,1 million.

Picture 1 presents passenger traffic distribution between regional and central airports over 1998-2009 time period. Regional airports experienced dynamic growth due to new airline entrance allowed by market deregulation. The decline in the number of flights in 2009 was caused by world wide crisis. In the 90's regional airports market share was of $24 \%$ and thanks to Low Cost Carriers' activity it has doubled in 2009.

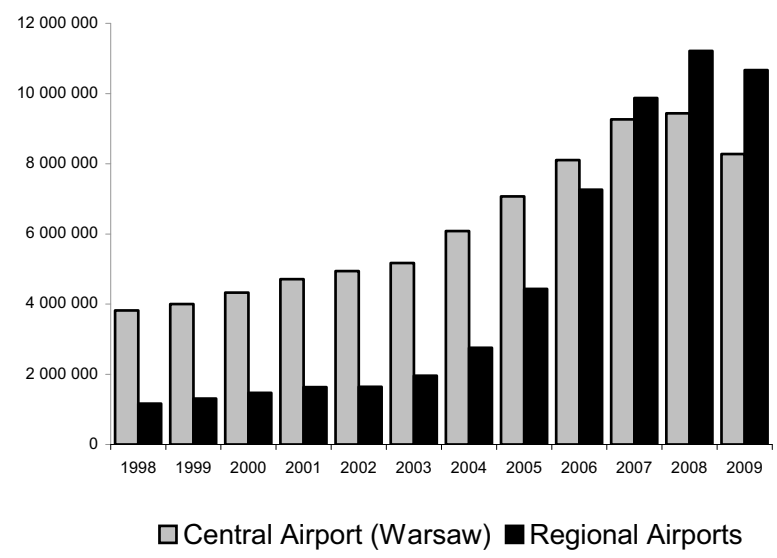

Chart 1. Development of passenger air traffic at Polish airports.

Source: Civil Aviation Authorities Air Traffic Statistic. Own compilation.

First Low Cost Airline which started to offer flights from Polish airports was Air Polonia, company which however ceased its operation at the end of 2004. Wizz Air and Rynair are examples of Low Cost Carriers that entered the market with success and are systematically increasing their market share. Regional airports with low airside charges, low ground handling service cost and better slot availability are much more attractive for LCC than central hub airport, therefore LCC's traffic share at regional airports in Poland is very high $^{2}$.

\section{Effects of liberalization}

Removing restrictions on market access equals a range of consequences. Allowing air carriers to operate on intra-European routes led to a direct impact on the number of air

\footnotetext{
${ }^{2}$ LCC's share at Katowice Airport - where Wizz Air has its operating base - constitutes more than $80 \%$ of regular traffic. Overall, LCC in Poland are responsible for carrying over 50\% of passenger.
} 
passenger flow. There is a significant evidence of a positive connection between the degree of market regulation and the volumes of traffic. Until 2004 passenger movement has increased systematically with average growth rate of 7,5\%. After market deregulation - when air traffic has boosted up at the regional airport particularly - the average dynamic rate was over $18 \%$.

Emerging new airlines - now under deregulated market conditions - have not only increased traffic volume but also changed route structure. Before 2004 there was roughly no air carrier competition on air routes which means that each city pair was served by one carrier. Also, there were almost no direct connections from regional airports - only four up to five available destinations to specific hub airports. Due to few changes made in the overall restriction policy - giving airlines permission to enter the market - numerous direct connections have been established. The following example of Poland - United Kingdom ${ }^{3}$ traffic development illustrates impact of deregulation on the route network. Until 2003 air traffic did not exceed 0,5 million passenger per year and in 2008 it was already ten times higher. Before the introduction of LCC, flights between Poland and Great Britain were offered exclusively by national carriers PLL LOT or British Airways. There were only five direct connections available - three from Warsaw Airport, one from Krakow Airport and one from Gdansk Airport. In 2009 British destinations had dominated route network at Polish airports. Thanks to LCC, more than 50 direct connections have been established. What's even more important, the passenger number served by national carrier has increased as well.

Better access to services, greater choice of carriers and routes, savings from low fares - all that improved significantly the welfare of passengers. Economies of scale, competition and new business model encourage airlines to offer service at lower price. Labour and equipment are being used more efficiently with carriers keen on providing more convenient service. Morrison and Winston (1986) estimated social welfare of 2,5 billion annual over 10 years after market deregulation in the US. Prior to air transport liberalization in Europe between 1992 and 2000 (EU 2003) - average fares declined by 34\% (in real terms). The main changes in Poland concerning air fares have made service available for citizens with average income. Earlier, the air market deregulation standard fare on Europe routes was at the level of EUR 400-500. Nowadays it is possible to pay for the ticket even ten times less. Lower fares and increased consumption lead to increase in consumer surplus ${ }^{4}$.

Development of air services market directly impacts aviation business growth and creates spillover effect all over economy. Increased volume of served passenger has brought revenue growth and allowed to create additional work places at all business entities related with aviation, airlines and airports in particular. Moreover, airports and airlines simply need to face challenges and develop their activity even further in order to meet the demands. Growth of purchases in case of airlines, airports and other aviation related entities supports growth among chain of suppliers ${ }^{5}$. Estimation of the deregulation effect on airport performance and changes in labour is illustrated in the following part.

\footnotetext{
${ }^{3}$ Prior to its accession into European Union, Poland gained access to the British labour market. Combining this with high unemployment rate in Poland and favourable pound exchange rate, Poles' mobility has increased and the traffic between Poland and UK has boosted up. Unofficial information sources estimated the immigration level at 1 million. Even now, low fares of air services and variety of direct connections offered by Low Cost Carriers encourage work emigrants to travel by plane.

${ }^{4}$ Consumer surplus can be defined as a difference between the price that consumers are willing and able to pay for air transport service and the price they actually pay. Therefore, consumer surplus increases if the price of a plane ticket decreased.

${ }^{5}$ Described effect is defined as an indirect impact (ACI, 1998). Still, estimating indirect impact is beyond scope of this study.
} 


\section{Economic effect of air transport liberalization in Poland}

This section focuses on impact of changes in air transport policy concerning welfare improvement in economy. Economic growth is measured by an increase in output (sales revenue) and employment at the airports ${ }^{6}$. The impact of air transport liberalization cannot be assessed simply by comparing economic situation before and after changes in policy, simply because changes in aviation business activities result from input price changes, as well as a regulatory change. A "counterfactual" scenario needed to be build along with a properly conducted evaluation of the welfare level achieved under actual regulation policy with the level that would have been achieved if an alternative regime had been in effect at the same time (Morrison, Winston, 1986).

A linear regression model was built in order to predict the air traffic volume that could occur if there had not been for change in government market control. Trend line was constructed based on flights number data in time series before 2004. Until 2004 passenger movement has increased systematically with average growth rate of $7,5 \%$. Should an assumption be made that there would be no significant changes which could affect the air traffic, one can predict further development of carried passenger volume. Black line on the picture number 2 reflects real change in passenger air traffic before and after liberalization. Grey line on the picture reflects predicted volume of passenger air traffic under regulated regime (a "counterfactual" scenario - without liberalization). One can assume that if not for the change in government policy toward access to air transport market, the air traffic in 2009 would be two times smaller comparing to scenario with air market liberalization, or even smaller since the "counterfactual scenario" does not take into account changes in economy as for example world wide crisis in 2008.

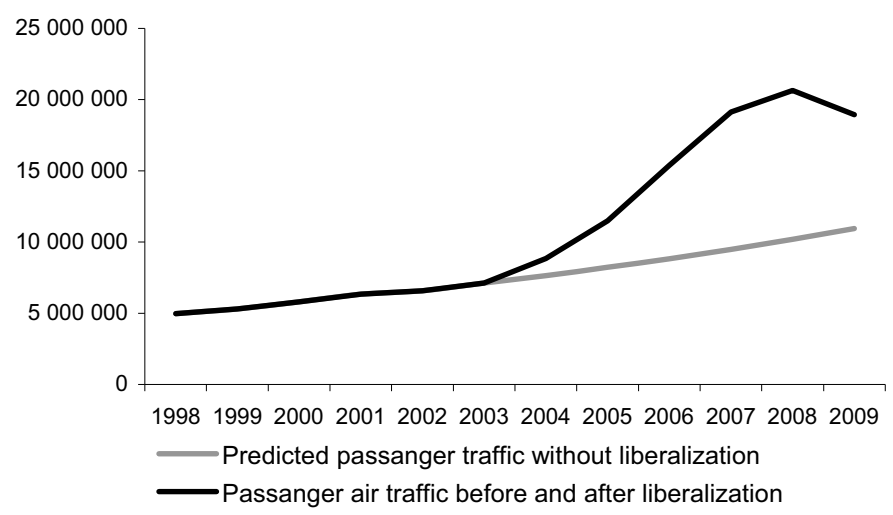

Chart 2. Prediction of passenger air traffic development with and without market liberalization.

Source: Civil Aviation Authorities Air Traffic Statistic. Own compilation.

Economic impact might be divided into airport impact and local economic impact. The airport economic impact results from changes in air traffic and affects airport output and

\footnotetext{
${ }^{6}$ Prior to changes in market regime, growth in economic activity does occur in all business related to air transport services: from airports, airlines, air navigation agencies, handling agents, suppliers network to already mentioned here business and tourism related entities. Yet an overall increase in output and employment plays the most significant role in case of airports.
} 
employment. Changes in access to external markets influence the airport regional economy (Gillen D., Hinsch H., 2001).

Airport revenues are positively correlated with air traffic. Aviation activities generate more than $80 \%$ of airports income. Passenger and airline charges are the main sources of revenues. Picture 3 illustrates the correlation between passenger traffic and sales revenue at main regional airports in Poland. Under government regime - when air transport market was stifled - the revenue level was developing rather constantly with slight growth rate. After market liberalization in 2004 a dynamic growth of both passenger number and revenues has taken place. Estimation of deregulation impact on the output level is based on five out of eleven regional airports in Krakow, Katowice, Gdansk, Poznan and Wroclaw and one central airport located in Warsaw. Air traffic market share of those six airport amounts $93 \%$.

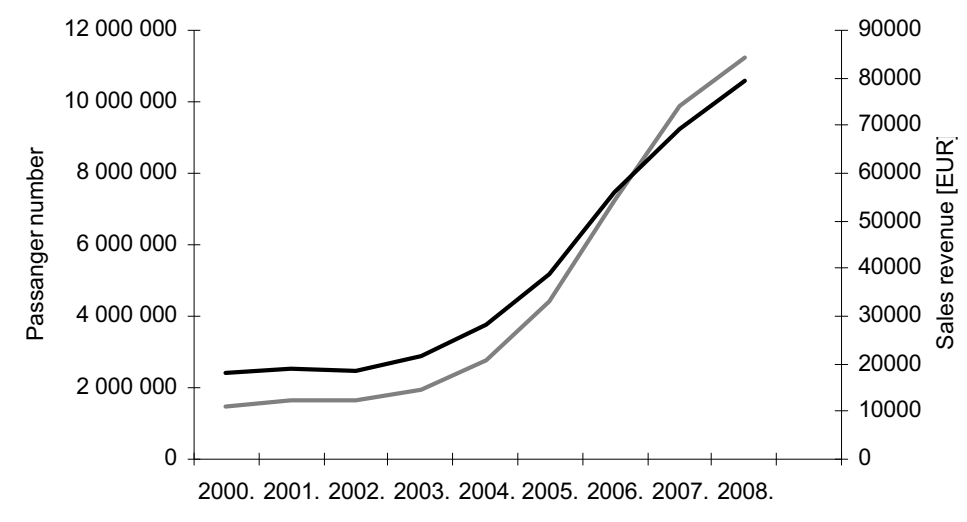

Traffic growth at regional airports _ Revenue growth at regional airports

Chart 3. Passenger traffic and airport sales revenue correlation at the main regional airports in Poland.

Source: Civil Aviation Authorities. Airports financial statements. Own compilation.

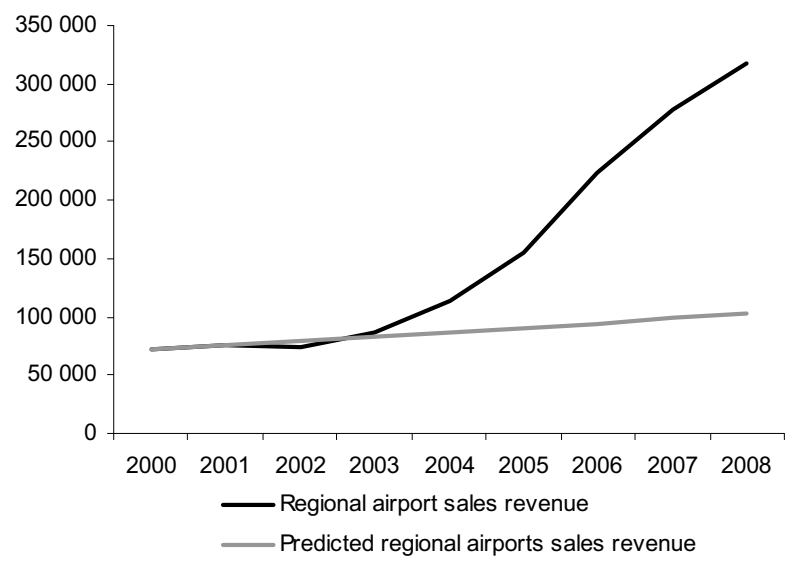

Chart 4. Sales revenue growth at the main regional airports in Poland - real and "counterfactual" scenario.

Source: Civil Aviation Authorities Air Traffic Statistic. Own compilation. 
"Counterfactual" scenario based on linear regression model was constructed. Development of the revenue of five regional airports collected in time series before 2004 was applied to build a trend line which helped to predict revenue expansion in the next years. There are no distinctions between aviation and non-aviation revenues. It is assumed however that both are affected by changes in air traffic. The difference between total revenues real value achieved under liberalized market rules and predicted figures that could have occurred without the market deregulation is the positive airport output effect of liberalization. One can assume that during the 2004-2008 time period the removal of access restriction on air transport market has created additional PLN 0,96 billion (or EUR 0,24 billion) of airports sales revenue in nominal value at current prices. In order to ensure additivity of annual revenues in time series for years 2004-2008, a deflation method to derive figures at constant prices needed to be applied. The data only permitted to use general price index to recalculate figures covering years 2004-2008 into constant prices with reference to year 2004. The preliberalization generated sales revenue in constant prices (2004) amounted PLN 969196740.

Revenue effect aside, explosive growth in flights and passenger number also means increased employment. Additional air traffic requires more labour force in order to serve additional air transport customers. The employment is increasing in direct and indirect environment (ACI Europe, 2004). The direct employment includes creation of jobs at the airport operator, airlines, aircraft maintenance and other firm located at the airport. The indirect employment means work places generated in the economy of the study area in the chain of suppliers of goods and services to the direct activities. One can distinguish these induced effect (ACI Europe, 2004), the employment generated by spending of incomes by the direct and indirect employees. Due to data availability and limited scope of this study only estimation of direct airport base operator employment is presented in this paper. Again, evaluation of liberalization effect on employment level in the economy is based on five out of eleven regional airports in Krakow, Katowice, Gdansk, Poznan, Wroclaw and one central airport located in Warsaw. The real number of work places at the regional airports and at the central airport at the base of 2008 year is assessed and compared with "counterfactual" scenario. Data were gathered directly form airport operators. In case of lack of employment data (two out of five regional airports) estimation of work places based on correlation with air traffic development was made. Picture 5 presents real change in airport base operator labour at five biggest regional airports and central airport in Poland in 2003 - just before liberalization - and in 2008 five years after market deregulation. These data are compared with work number in "counterfactual" scenario. The total base operators employment at main regional airports and one central airport in 2008 was around 3500, and has grown about 93\% at regional airports and $22 \%$ at central airport when compared with 2003 year when access to air market was regulated. In order to measure the impact of liberalization on increase in employment at the airport, the "counterfactual" scenario based on employee to air passenger traffic ratio was constructed. The difference between real number of work places in 2008 and the predicted number is the effect of liberalization. One can assume that if it has not been for transformation in air transport policy, there would be 623 work places less at the airport base operators in Poland. This is estimated number of jobs that have been created as a result of increased air traffic caused by changes in market access regulation. The increase in employment seems to be non significant at only 623 work places. However, direct impact encompasses not only change in labour force at the base operator but also in all activities located at the airport. Growth of flight number affected jobs at the airlines, aircraft maintenance and other companies located at the airport. In 2003 total direct employment at the main regional and the central airports in Poland was near 7 thousands. This number corresponds with average passenger per employee ratio in Europe, each million passengers per annum creates 950 on-site jobs (ACI Europe, 2004). In Poland this ratio was of 1011 in 
2003. Estimation made on air traffic development on time series 2003-2008 indicates that passenger traffic of 19,4 million created more than 19 thousand jobs located on-site and offsite at main Poland's airports in 2008.

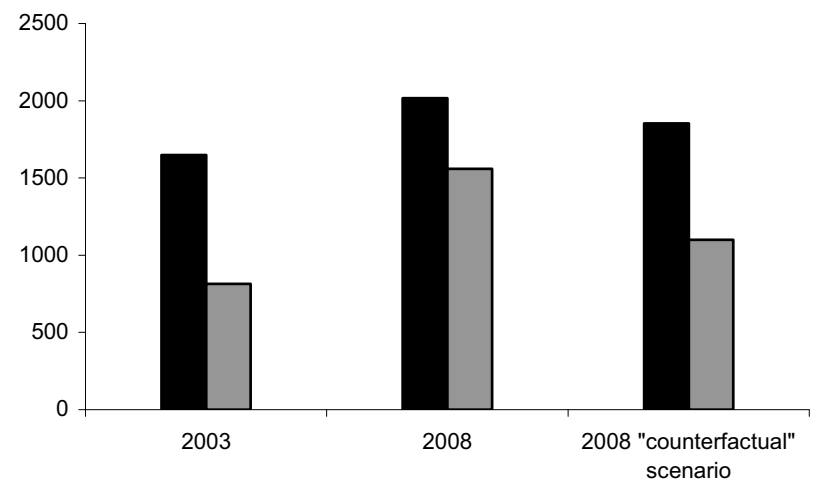

Employment at central airport $\square$ Employment at main regional airports

Chart 5. Airport base operator employment at main airports in Poland - real and "counterfactual" scenario.

Source: Airports employment data. Own estimation and compilation.

One can assume that were it not for a change in market regulation and a vigorous development which followed, the total direct employment number would be half of the one present in 2008.

\section{Conclusion}

Market deregulation - by enhancing competition - leads to increased consumption mainly due to wider choice of products or services and lower costs which are directly connected with more efficient delivery. Air transport liberalization that has taken place on Poland's accession to European Union has brought various benefits to stakeholders. Among many others, economic impact is the one that can be measured quite precisely. Changes in the welfare level evaluated in two cases - with and without liberalization, with this specific subject being the core objective of this paper. The results reveal significant importance of free air transport market to the regional and national economy. Air traffic has more than doubled within five years after liberalization and experts estimate that without the policy change it would currently be only $20 \%$ higher than when compared with 2004 . Removing restrictions concerning access to air transport market has created additional PLN 0,96 billion (or 0,24 billion EUR) of main airports sales revenue and additional 9 thousands jobs located on-site and off-site at Poland's main airports over 2004-2008 time period.

This analysis cannot measure a complete impact of deregulation, it does give however some insight into the importance of competitive and international air market. In order to make specific decisions concerning changes in the market regulation a full study of costs and benefits - especially those that take into account economic, social and environment effects should be conducted. The model presented in this paper identifies those stakeholders particularly passengers and airports, that would gain from air transport liberalization.

The opponents to the air transport deregulation quite often see it as a threat to a protected environment. They quite often raise arguments which are mainly focused on an 
insecurity of a flag carrier on a highly competitive market. Still, many of those who oppose could gain significantly from such process, should they be ready to face transitional risks and modify their business model (InterVistas-ga2 Consulting, 2006). Despite the fact that flag carriers in Poland lost market shares but not market volume, there was an obvious need to revise cost structure and face low cost carriers competition.

\section{References}

1. ACI Europe, 2004, The social and economics impact of airports in Europe, Airport Council International, Brussels

2. Armstrong K.A., Bulmer S., 1998, The Governance of the Single European Market, Manchester University Press, Manchester and New York

3. Button K. J., Sough R., 2000, Air transport networks: theory and policy implication, Edward Elgar Publishing

4. Button K., Taylor S., 2000, International air transportation and economic development, Journal of Air Transport Management, vol 6, pp 209-222

5. European Union, 2003, The effect of air transport liberalization on fares, Brussels

6. Gillen D. Hinsch H., 2001, Measuring the economic impact of liberalization of international aviation on Hamburg airport, Journal of Air Transport Management, vol 7, pp 25-34

7. InterVISTAS-ga2 Consulting, 2006, The economic impact of air services liberalization, Washington

8. Morrison S., Winston C., 1986, The Economic Effects of Airline Deregulation, The Brookings Institution, Washington

9. Staniland M., 2003, Government Birds, Air Transport and the State in Western Europe, Rowman and Littlefield Publishers, Inc

10. The Airline Deregulation Act, 1978, Pub.L. 95-504

11. The Centre of European Information, 2002, Transport policy, Poland and European Union negotiation

12. The economic regulation of airports: recent developments in Australasia, North America and Europe, 2006, ed by Forsyth Peter; German Aviation Research Society, Ashgate 